\title{
The relationship between study anxiety and academic performance among English students
}

\author{
Sukardi Weda - Andi Elsa Fadhilah Sakti
}

DOI: 10.18355/XL.2018.11.02.56

\begin{abstract}
This study explores the relationship between study anxiety and academic performance among English students at Faculty of Languages and Literature Universitas Negeri Makassar, Indonesia. A total 116 students, 96 females and 20 males students participated in this study. This study focuses its investigation on a significant correlation of students' study anxiety and their academic performance. There were two types of instruments used, a questionnaire and a test. The study anxiety level was measured using Sansgiry and Sail's Test Anxiety Measurement (TAM). Meanwhile, students' academic performance was measured using Grade Pont Average (GPA). The results revealed that there was a significant correlation of high level anxiety and low academic performance among English students at Faculty of Languages and Literature Universitas Negeri Makassar, with significant correlation $(p=0.011)$ and the correlation coefficient is small with $r=0.235$. Further studies in a wide variety of settings with students who have different socio economic background, gender, motivation, achievement, and other disciplines with students' study anxiety are recommended.
\end{abstract}

Key words: Study anxiety, academic performance, English students

\section{Introduction}

There is no doubt that English is the most intriguing subject at schools and universities. This is because by knowing English, someone can obtain information from other countries. He or she can express his or her ideas, thoughts, and feelings in English. Hence, English is assumed as a basic requirement to participate in the international arena as an academician and scholar. Dealing with the quality of teaching English as a foreign language (EFL) in Indonesia, many researchers reported that the quality of teaching English is still low. One of the influential factors contributing to the low English proficiency is anxiety (Vitasari et al, 2010; Woodrow, 2006; Oya et al, 2004; Abu-Rabia, 2004; Arjanggi et al, 2016).

Trang, Moni \& Baldauf (2012) reveal that there are a variety of factors that might influence foreign language learning faced by a number of students when learning a foreign language; attitude, motivation, anxiety, and beliefs. Of these affective factors, anxiety has been given much attention. Anxiety is associated with feelings of uneasiness, frustration, self-doubt, apprehension, or worry (Brown, 1994). Nunan and Lamb (1996) argue that most people seem to believe that anxiety is detrimental to effective learning and that the first task for the language teacher is to reduce anxiety in the learner. Accordingly, Wang and Roopchund (2015) argue that as an affective factor, anxiety has been found to have a debilitating effect on the language learning process. One of the affective variables addressed lately is the "anxiety of FL learning." This current study, therefore, addresses the question; is there any relationship between study anxiety and academic performance among English students at State University of Makassar Indonesia?. 


\section{Literature Review}

\subsection{Previous Related Studies}

Studies on language anxiety have recently begun to investigate a wide variety of learners' anxiety in language learning, ranging from the relationship between students' anxiety and their academic performance. Vitasari et al (2010) reported that there was a significant correlation of high level anxiety and low academic performance among engineering students. Woodrow (2006) argued that second language speaking anxiety to be a significant predictor of oral achievement. Oya et al (2004) found that there was significant correlation between extraversion and global impression scores, and state anxiety and clause accuracy scores. In keeping with Liu \& Huang (2011), who reported that there are two important affective variables, anxiety and motivation have been found to be highly correlated to second/foreign language acquisition. Similarly, Cheng (2002) also reported that ANOVA results demonstrated that female students in this study reported experiencing significantly higher levels of L2 writing anxiety than male students.

These findings suggest that participants who were more extraverted produced better global impressions during their oral performance, and those who were experiencing higher level of state anxiety made more errors in their spoken use of clauses. Abu-Rabia (2004) found that female students showed higher anxiety than male students. Accordingly, the male students' achievements were also higher than the female students' achievements. Arjanggi, et al. (2016) reported in their study that the lower the students' social anxiety, the more students' academic adjustment will be.

\subsection{Anxiety}

Numerous empirical studies have revealed that anxiety has relationship and influence on academic performance (Oya et al, 2004; Saito \& Samimy, 1996; Young, 1986; \& Vitasari et al, 2010). A range of factors was revealed to contribute to anxiety such as low English proficiency, lack of practice, personality, fear of making mistakes and being laughed at, competition, and lack of confidence (Liu, 2006).

Anxiety is defined as fear, panic, and worry (Abu-Rabia, 2004). Ellis (Abu-Rabia, 2004) argues that the FL learner characterized as having anxiety is usually worried, physically insecure, and unable to engage in situational learning. Students with anxiety disorder exhibit a passive attitude in their studies such as lack of interest in learning, poor performance in exams, and do poorly on assignments (Vitasari et al, 2010).

Anxiety is usually perceived as exerting a negative effect on the learner (Abu-Rabia, 2004). However, Alport \& Haber (Abu-Rabia, 2004) distinguish two types of anxiety: debilitating anxiety, which negatively affects the learner's engagement in the learning situation, and facilitating anxiety, which motivates the learners to cope with the new assignment.

Woodrow (2006) states that in educational research, anxiety is usually classified as being trait or state. Trait anxiety is a relatively stable personality trait. A person who is trait anxious is likely to fell anxios in a variety of situations. State anxiety, on the other hand, is a temporary condition experienced at a particular moment. A third type of anxiety is situation specific anxiety. This reflects a trait that recurs in specific situations (Spielberger, Anton, \& Bedell in Woodrow, 2006).

Vitasasri et al (2010) argue that anxiety is a specific-situation that refers to anxiety conditions that are experienced during study process and could be disturbance of academic performance. They therefore add that study anxiety has two dimensions include physiological arousal and cognitive anxiety as revealed in Figure 1.

XLinguae, Volume 11, Issue 2, April 2018, ISSN 1337-8384, eISSN 2453-711X 


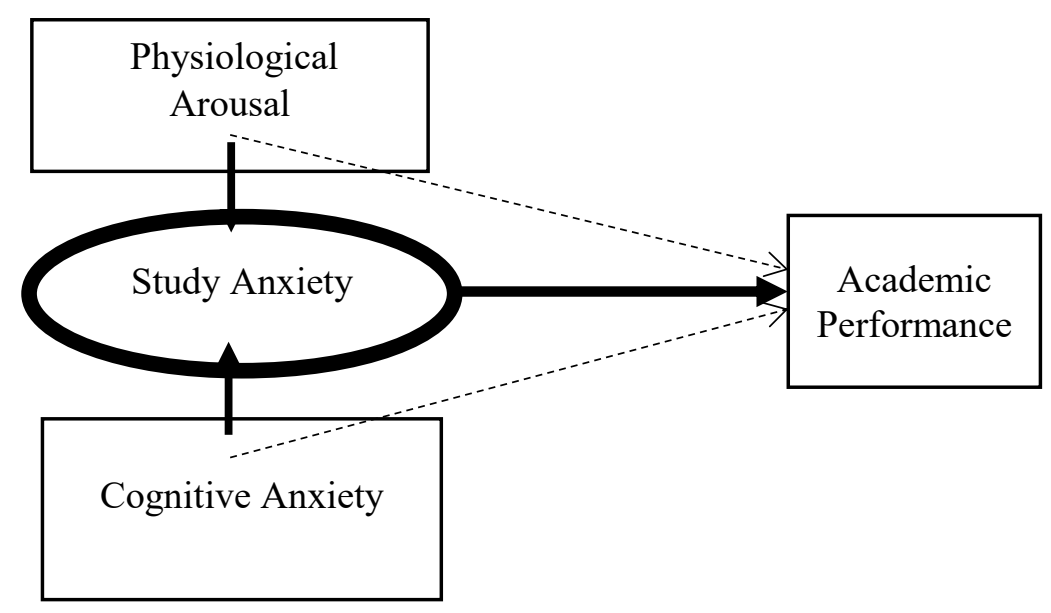

Figure 1. Theoretical model of study anxiety upon academic performance (Vitasari et al, 2010)

Anxiety reactions can be categorized as reflecting worry or emotionality (Leibert \& Morris in Woodrow, 2006). Emotionally, anxiety refers to physiological reactions, such as blushing or racing heart, and behavioural reactions, such as, stammering and fidgeting. Worry refers to cognitive reactions, such as selfdeprecating thoughts or task irrelevant thoughts (Zidner, 1998; Naveh-Benjamin, 1998 in Woodrow, 2006).

\subsection{Teachers' Attitude and Foreign Language Anxiety}

Tobias (Abu-Rabia, 2004) states that FL anxiety is highly related to the inner self and the self-expression of the learner, which are strongly interwoven. Aida (Saito \& Samimy, 1996) studied language anxiety of beginning language learners of Japanese at the university level. One of Aida' research findings was that that overall language anxiety was negatively related to students' performance in Japanese. In addition, when students were classified into a high-anxiety group and a low-anxiety group by a median split procedure, the high-anxiety group received significantly lower grades than the low-anxiety group Saito, Samimy (1996) argue that foreign language anxiety is a factor that significantly influences foreign and second language acquisition.

Therefore, as a facilitator in the English as a Foreign Language (EFL) classroom, teacher's characteristics are important in promoting success in learning situations (Lam in Abu-Rabia, 2004). According to Lam (Abu-Rabia, 2004), successful teaching depends on the teacher's optimal involvement in the learning material and interest in the learner. Lam, therefore, argue that there are several characteristics that characterize the good teacher as follows:

1. Relaxation: a relaxed teacher reflects this quality onto the class learning climate, which ultimately yields desirable learning communication between teacher and student and among students;

2. Openness: this enables the teacher to know him/herself and to communicate with others in seeking information that may be helpful for the learning environment; and

3. Originality and spontaneity: this is an indicator of clear communication between the self and the person, where the person is open with him/herself. 
Thus, to improve students' involvement and motivation in the EFL classroom, a teacher needs to nurture students' self confidence and reduce students' study anxiety by providing a wide variety of interesting and challanging classroom activities.

Harmer (1991) state that it is clearly the case that physical conditions have a great effect on learning and can alter a student's motivation either positively or negatively. According to Harmer, classrooms that are badly lit nd overcrowded can be excessively de-motivating, but unfortunately, many of the exist in schools. We can say, then, that the atmosphere in which a language is learnt is vitally important (Harmer, 1991). Accordingly, Liu (2006) argues that the students hoped their teachers would take measures to help them become more confident such as creating a friendly classroom atmosphere and providing interesting topics and practice time for speaking English.

\section{Method}

\subsection{Participants}

A total of 116 participants were participated in this study. The participants were students of English Education Study Program, English Literature Study Program, and Business English D-III Study Program of Faculty of Languages and Literature State University of Makassar, and the students of TEFL Study Program of Graduate Program State University of Makassar, Indonesia, and the detail is revealed in figure 2 .

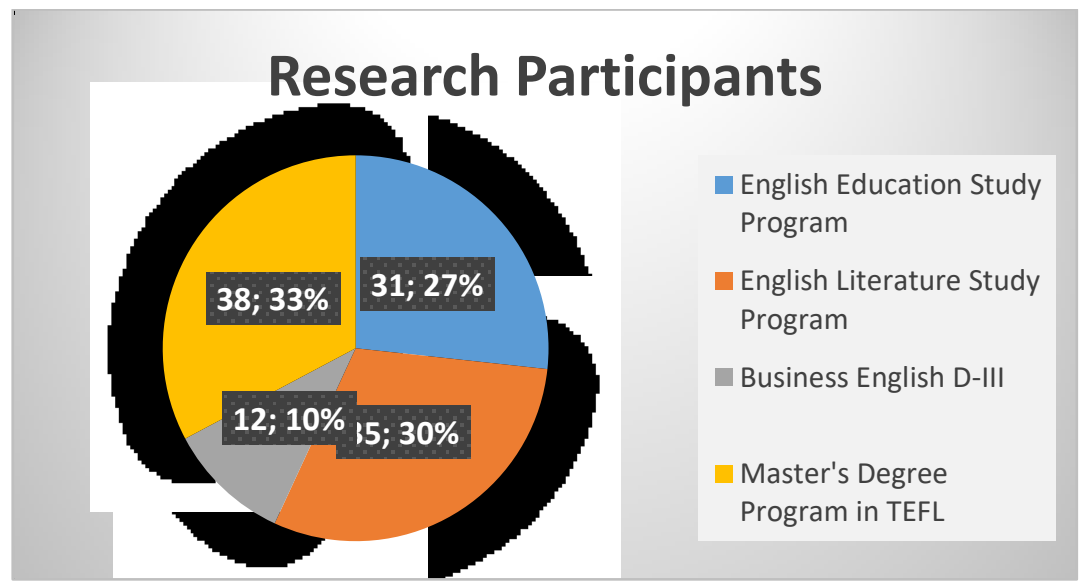

Figure 2. Research participants

\subsection{Procedure, Instrument, and Measurement}

The test aimed to find the relationship of study anxiety and academic performance among English students of Faculty of Languages and Literature Universitas Negeri Makassar. Data about study anxiety were collected during a class lecture in November 2017. The students came to the class and filled in the questionnare which consisted of 10 items. Results of the test was used to find out the correlation between study anxiety and students' academic performance (Grade Point Average/GPA). The study anxiety level was measured using Sansgiry and Sail's Test Anxiety Measurement (TAM) which consists of 10 items. A scale that measured test-

XLinguae, Volume 11, Issue 2, April 2018, ISSN 1337-8384, eISSN 2453-711X 
anxiety inventory was validated by Sansgiry and Sail (2006). In this research, the respondents were asked to rate their emotions with response to test anxiety on a 5point scale on which $1=$ not at all typical of me; $2=$ not very typical of me; $3=$ somewhat typical of me; 4 = fairly typical of me; and $5=$ very much typical of me. Meanwhile, students' academic performance was measured using Grade Pont Average (GPA). The GPA is to measure students' academic performance. The GPA was obtained from the questionnaire in which the students were asked to record their GPA on the questionnaire. The classification of the academic performance level of some universities in Indonesia justifies low academic performance is GPA $\leq 3.0$; moderate is within the range $3.1-3.6$; and high is $\geq 3.7-4$. The interpretation of TAM and GPA level are revealed in table 1.

\begin{tabular}{ccc} 
Table 1. Interpretation of GPA Level & \\
\hline TAM's Score & $G P A$ & Interpretation \\
\hline $40>$ TAM & $3.0>$ GPA & Low \\
$40<$ TAM & $3.4<$ GPA & High \\
\hline
\end{tabular}

\subsection{Data Analysis}

Data were coded and analyzed using the SPSS with a priori set alpha level of 0.05 . The relationship of study anxiety upon academic performance was examined by Pearson correlation. The significant coefficient and coefficient correlation are examined to find out the results. The mean and Standar Deviation (SD) are also calculated using descriptive statistics.

\section{Result and Discussion}

\subsection{Demographic of Participants}

There were 116 students participated in this study to test their anxiety level. The students were from 4 majors; there were 31 students from Undergraduate degree in English Education Study Program, there were 35 students from Undergraduate degree in English Literature Study Program, there were 12 students from Business English D-III Study Program of Faculty of Languages and Literature State University of Makassar and there were 38 students from TEFL Study Program of the Graduate Program of State University of Makassar. The participants' age ranged from $18-38$ years old. The demographic profile of participants is revealed in detail in table 2 as follows. 
Table 2: Demographic of Participants

\begin{tabular}{|c|c|c|c|}
\hline & $\begin{array}{l}\text { Demographic } \\
\text { Information }\end{array}$ & $\begin{array}{c}\text { Freque } \\
\text { ncy }\end{array}$ & $\begin{array}{l}\text { Percent } \\
\text { age }\end{array}$ \\
\hline \multicolumn{4}{|l|}{ Gender } \\
\hline & 1. Female & 96 & 82.76 \\
\hline & Male & 20 & 17.24 \\
\hline \multicolumn{4}{|l|}{ Major } \\
\hline & 1. English & 31 & 26.72 \\
\hline & Education & & \\
\hline & (Undergraduate) & & \\
\hline & 2. English & 35 & 30.17 \\
\hline & Literature & & \\
\hline & (Undergraduate) & & \\
\hline & 3. TEFL (Graduate) & 38 & 32.76 \\
\hline & 4. Business English & & \\
\hline & DIII & 12 & 10.34 \\
\hline \multicolumn{4}{|l|}{ Age } \\
\hline & 1. $18-20$ & 37 & 31.89 \\
\hline & 2. $21-29$ & 70 & 60.34 \\
\hline & 3. $\geq 30$ & 19 & 16.38 \\
\hline
\end{tabular}

\subsection{Anxiety Test Scores of English Students}

The scale that was used to measure test anxiety was reliable, with a Cronbach's alpha value of 0.7 (table 3). In general, students in this current study revealed that low to moderate test anxiety (15-45) out of a possible maximum of 5 (very high).

Approximately $20.7 \%$ of students revealed experiencing failure to perform better during examination. Approximately $31.9 \%$ of students experienced some level of anxiety during examinations even though they well prepared to complete the test. Approximately $31 \%$ of students indicated experiencing nervousness during the test. Approximately $26.7 \%$ of students exhibited physical symptoms such as perspiration, $19.8 \%$ of students exhibited physical symptoms such as stomach upset and increased heart beats $(19.8 \%)$ while they took the examination. Furthermore, $46.6 \%$ of the students indicated that they were somewhat bothered by taking exam and approximately $27.6 \%$ of the students revealed that they find themselves thinking of things unrelated to the actual study material during exams. 
Table 3. Anxiety Test Scores of English Students

Table 3. Anxiety Test Scores of English Students

\begin{tabular}{|l|c|c|c|c|c|c|}
\hline Variable* & $\begin{array}{c}\text { Not at } \\
\text { all } \\
\text { typica } \\
\text { lof } \\
\text { me, } \%\end{array}$ & $\begin{array}{c}\text { Not } \\
\text { very } \\
\text { typical } \\
\text { of me, } \\
\%\end{array}$ & $\begin{array}{c}\text { Some } \\
\text { what } \\
\text { typica } \\
\text { lof } \\
\text { me, } \\
\%\end{array}$ & $\begin{array}{c}\text { Fairly } \\
\text { typical } \\
\text { of me, } \\
\%\end{array}$ & $\begin{array}{c}\text { Very } \\
\text { much } \\
\text { typical } \\
\text { of me, } \\
\%\end{array}$ & $\begin{array}{c}\text { Mean } \\
\text { (SD) }\end{array}$ \\
\hline Failure to & 2.6 & 29.3 & 47.4 & 14.7 & 6.0 & $2.9(0.8)$ \\
perform better & 5.2 & 19.0 & 44.8 & 19.8 & 11.2 & $3.1(1,0)$ \\
Nervousness & 6.0 & 27.6 & 39.7 & 20.7 & 6.0 & $2.9(0.9)$ \\
Perspiration & 8.6 & 27.6 & 36.2 & 22.4 & 5.2 & $2.8(1.0)$ \\
Task-irrelevant \\
cognitions
\end{tabular}

Cronbach alpha $=0.7$

*Refer to Appendix for item description

4.3 The Relationship of Study Anxiety and Academic Performance

The Pearson correlation examines the relationship between study anxiety and academic performance. The results reveal mean and standard deviation (SD) of TAM ( $\mathrm{M}=28.43$ (moderate) out of a possible maximum of 5 (very high); $\mathrm{SD}=6.27665$ and GPA $(\mathrm{M}=3.62 ; \mathrm{SD}=0.28137)$, a significant correlation $(\mathrm{p}=0.011)$, the correlation coefficient is small with $\mathrm{r}=-.235$, and the sample size yield $\mathrm{n}=116$. Study anxiety is negatively related to academic performance with the participants' anxiety scores. Therefore, the finding implies that there is a significant relationship between high level anxiety and low academic performance among English students at State University of Makassar, Indonesia.

This present study is consistently with some previous studies on anxiety which reported that there was a significant relationship between the high level of anxiety and low academic performance. Vitasari et al (2010) argue that there was a significant correlation of high level anxiety and low academic performance among engineering students. Oya et al (2004) report that participants who were more extraverted produced better global impressions during their oral performance and those who were experiencing a higher level of state anxiety made more errors in their spoken use of clauses. The lower the students' social anxiety, the more students' academic adjustment will be (Arjanggi et al, 2016). Woodrow (2006) claims that second language speaking anxiety to be a significant predictor of oral achievement. Saito \& Samimy (1996) argue that foreign language anxiety can have a negative 
impact on Japanese learners' performance. Anxiety was negatively and significantly correlated to FL achievement on all FL tests (Abu-Rabia, 2004). At least one-third of the students at all proficiency levels self-reported feeling anxious in oral English lessons, though most were only moderately nervous. Others became so tense that their mouths or legs were shaking. This anxious feeling made many students unwilling to volunteer to speak Engl

ish in class (Liu, 2006).

Table 3.Results of Correlation between Study Anxiety and Students Academic Performance

\begin{tabular}{ccccc}
\hline Measures & Mean & SD & $r$ & $p$ \\
\hline TAM & 28.43 & 6.27665 & & \\
GPA & 3.62 & 0.28137 & & \\
TAM-GPA & & & -0.235 & 0.011
\end{tabular}

Note. $\mathrm{P}<0.05$

\section{Conclusion}

This current study represents an attempt to explore the relationship between study anxiety and students' academic performance. The results revealed that there was a significant correlation of high level anxiety and low academic performance among English students at Faculty of Languages and Literature Universitas Negeri Makassar, with significant correlation $(p=0.011)$ and the correlation coeficient is small with $r=0.235$. Students who have high level study anxiety achieve low academic performance in EFL classroom. High score of TAM reveals that students who have a higher score in anxiety achieve low GPA. This finding supports previous research that anxiety is a serious issue in Chine EFL classrooms and is not yet being addressed by many EFL teachers and learners (Liu, 2006). Further studies in a wide variety of settings with students who have different socio economic background, gender, motivation, achievement, and other disciplines with students' study anxiety are recommended.

\section{Bibliographic references}

ABU-RABIA, S. 2004. Teachers' Role, Learners' Gender Differences, and FL Anxiety among Seventh-Grade Students Studying English as a FL. Educational Psychology, Vol. 24, No. 5, October 2004, pp. 711-721. ISSN 0144-3410 (print)/ISSN 1469-046X.

ARJANGGI, R. - KUSUMANINGSIH, L. P. S. 2016. The Correlation between Social Anxiety and Academic Adjustment among Freshmen. Procedia Social and Behavioral Sciences, 219 (2016), pp. 104-107.

BROWN, D. H. 1994. Principles of Language Learning and Teaching. New Jersey: Prentice Hall, Inc.

CHENG, Y-S. 2002. Factors Associated with Foreign Language Writing Anxiety. Foreign Language Annals, Vol. 35, No. 5, pp.647-656.

HARMER, J. 1991. The Practice of English Language Teaching. New York: Longman. ISSN 0582-04656 4.

LIU, M. - HUANG, W. 2011. An Exploration of Foreign Language Anxiety and English Learning Motivation. Educational Research International, Volume 2011, pp. $1-8$. 
LIU, M.. 2006. Anxiety in EFL Classrooms: Causes and Consequences. TESL Reporter 39, 1 (2006), pp. 13-32.

NUNAN, D. - LAMB, C. 1996. The Self-directed Teacher: Managing the Learning Process. Cambridge: Cambridge University Press.

OYA, T. - MANALO, E. - GREENWOOD, J. 2004. The Influence of Personality and Anxiety on the Oral Performance of Japanese Speakers of English. Applied Cognitive Psychology, 18, 2004, pp. 841-855.

SANGSGIRY, S.S. - SAIL, K. 2006. Effect of Students' Perceptions of Course Load on Test Anxiety. American Journal of Pharmaceutical Education, 70 (2), pp. 1-6.

SAITO, Y. - SAMIMY, K. K.1996. Foreign Language Anxiety and Language Performance: A Study of Learner Anxiety in Beginning, Intermediate, and AdvancedLevel College Students of Japanese. Foreign Language Annals, 29, No. 2, 1996, pp. 241-249.

TRANG, T. T. T. - MONI, K. - BALDUF, R. B. 2012. Foreign Language Anxiety and Its Effects on Students' Determination to Study English: To Abandon or Not to Abandon?. TESOL in Context, Special Edition S3: November 2012, pp. 1-14.

VITASARI, P. - WAHAB, M. N. A. - OTHMAN, A. 2010. The Relationship between Study Anxiety and Academic Performance among Engineering Students. Procedia, Social and Behavioral Sciences, 8 (2010), pp. 490-497.

WANG, P. - ROOPCHUND, R.. 2015. Chinese Students' English-speaking Anxiety in Asking Questions in the MSc TESOL Classroom. International Journal of English Language Teaching, Vol. 2, No. 2; 2015, pp.1-17. ISSN 2329-7913/E-ISSN 23297921

WOODROW, L. 2006. Anxiety and Speaking English as a Second Language. Regional Language Center Journal, 37.3, pp.308-327.

YOUNG, D J. 1986. The Relationship between Anxiety and Foreign Language Oral Proficiency Ratings. Foreign Language Annals, 19, No. 5, 1986, pp. 439-445.

Appendix. Sansgiry and Sail's Test Anxiety Measurement (TAM)

For the following statements, please rate yourself according to how well each statement describes you:

$1=$ Not at all typical of me; $2=$ Not very typical of me; 3 = Somewhat typical of me;

$4=$ Fairly typical of me; and $5=$ Very much typical of me

1.Thoughts of doing poorly interfere with my performance on exams.

2.During an examination I frequently get some nervous that I forget facts I really now.

3. While taking an important exam, I perspire a great deal.

4.During exams, I find myself thinking of things unrelated to the actual study material.

5.I feel very panicky when I have to take an exam.

6.After important tests, I am frequently so tense that my stomach gets upset.

7.I usually feel my heart beating very fast during an exam.

8.I usually get very depressed after taking an exam.

9.I wish exams did not bother me so much.

10. Even when I well prepared for a test, I feel very anxious about it.

Words: 3493

Characters: 22749 (12,64 standard pages) 
assoc. prof. Dr. Sukardi Weda, S.S., M.Hum., M.Pd., M.Si., M.M., M.Sos.I., M.A.P. Andi Elsa Fadhilah Sakti

English Department

Universitas Negeri Makassar

Jl. Dg. Tata, Kampus UNM Parangtambung Makassar

Indonesia

sukardi.weda@unm.ac.id

andielsafadhilas@yahoo.co.id 